\title{
The Rise and Fall of Partitive Markers in Some Germanic Varieties
}

\author{
Thomas Strobel and Elvira Glaser
}

\section{1 \\ Introduction}

The purpose of this contribution is a comparative analysis of different "partitive markers" in the noun phrase of several Germanic varieties, with a special focus on areally peripheral non-standard or less standardized West Germanic varieties. Starting with the use of genitive case for the marking of partitive functions in various syntactic contexts in the older stages of German, we then take a closer look at those varieties for which the survival of at least some genitive forms and functions related to partitive meanings is reported in modern times. This is true for some Highest Alemannic dialects in Switzerland (Henzen 1932, 122-124; Szadrowsky 1937, 1940) and for Lëtzebuergesch, both the dialects and the Koiné (Döhmer 2017). ${ }^{1}$ We would like to emphasize, however, that for Highest Alemannic recent data are lacking completely. While there is some recent research on the more widely existing pronominal remnants of partitive genitive forms (see Strobel 2017), there is in general much less information concerning the expression of partitivity within the noun phrase (see Glaser 1992, 1993; Grestenberger 2015).

In the following, we will focus on the expression of (pseudo-)partitivity ${ }^{2}$ in Walliser (and Walser) German (Highest Alemannic) as well as in Luxembourgish (Moselle Franconian). We will give an outline on the formation and distribution of the relevant structures involving genitive forms with determiners and/or nouns, comprising independent partitive genitives not directly governed by some head (Seržant 2014). Our overview is based on various sources, including recent inquiries and fieldwork. We will show to what extent the meaning of partitivity is still present in these structures and discuss the over-

1 For the sociolinguistic situation of Lëtzebuergesch and the history of standardization see Gilles (2006).

2 With the differentiation between partitivity and pseudo-partitivity, we follow the terminology of Koptjevskaja-Tamm (2001), in concise form Koptjevskaja-Tamm (2006), based on Selkirk (1977). 
lap with other forms, as for example the use of bare nouns. When the genitive marking is restricted to the determiner and no longer present with the noun, these constructions pattern with the distribution of the so-called "partitive article" in French and Italian. Given that Highest Alemannic and Luxembourgish both are situated in the Germanic-Romance contact zone, the question of contact influence comes up. As in other varieties, the loss of the genitive is accompanied by the development of new markers or the reuse of forms in order to mark partitivity, such as the preposition von 'from, of' in Southern Rhine Franconian (Glaser 1992) or equivalent van in Dutch (Luraghi and Kittilä 2014, 23). A hitherto unsolved problem concerns the rather unclear relation to the use of the indefinite article with mass nouns in Bavarian (cf. e.g., Kolmer 1999) and the "non-delimited use" of the definite article in such contexts in some peripheral Swedish dialects (Dahl 2015, 50, 54).

Occasionally, we will also draw a comparison to the corresponding pronominals, since both in Romance and Germanic there are varieties with "partitive" pronouns and determiners (French, Italian; Walliser and Walser German, Luxembourgish) as opposed to systems with "partitive" pronouns but without the respective determiners (Catalan; Dutch, Central German dialects). ${ }^{3}$ This leads to the question of why the pronominal use seems to have survived longer than the nominal use in these latter varieties.

The paper is organized as follows: in Section 2, we provide a short overview on the development and decline of the partitive genitive in the history of German, Section 3 presents newly elicited data and their analysis in Walliser German and Luxembourgish, both varieties still showing remnants of the partitive genitive. Section 4 concludes the paper.

\section{The Historical Background}

We take as a starting point the fact that in the older Germanic languages, as in other Indo-European languages, one of the functions of genitive case is the marking of partitivity and pseudo-partitivity (Luraghi and Huumo 2014). There is also an independent partitive genitive (IPG), whose main function is, in correspondence with Seržant (2014), the partial affectedness of the referent. This can be illustrated by examples from Old High German (онG, 700-1050 AD), where we find genitive case in object position $(2)-(3)$ as well as in subject posi-

3 Cf. Stark and Gerards, this volume, for a discussion of "partitive articles" in Francoprovençal. 
tion (1), which is, however, much rarer. The genitive can cover a functional range from deictic use to indefinite readings, often difficult to distinguish in the given context of the historical sources. ${ }^{4}$ In (1) there is no wine mentioned in the context, whereas in (2) there is a spring (puzzi) mentioned before. In (3), too, the text is referring to the oil of the wise virgins already mentioned. But in all these cases, there is some kind of partial reading involved, whether it is a part of a definite quantity or an undefined amount of a substance.

(1) OHG

joh brast in thar thes win-es

also was.lacking them there the.GEN.M wine-GEN.M

'and they also lacked wine' (O. 2.8.11)

(2) OHG

so quam ein uuib thara tho [...] thes uuazar-es giholoti

so came a woman there then [...] the.GEN.N water-GEN.N get

'a woman was coming there in order to get some (of the) water' (O. 2.14.14)

(3) OHG

kebet uns iuuar-es ol-es

give us your-GEN.N oil-GEN.N

'give us some of your oil' (Mons. 20.1)

The situation did not change much in Middle High German (MHG, 1050-1350 $\mathrm{AD})$, where we find genitive case in the functions mentioned above, in particular in object position (4)-(5), but also in subject position (6). The examples show both indefinite articles in (4) and (5) and a definite article in (6):

(4) MHG

er [...] tranc dazuo ein-es wazzer-s daz er vant in

he $[. .$.$] drank with it a-GEN.N water-GEN.N that he discovered in$ einem einber an der want

a bucket at the wall

'he drank some water with it that he discovered in a bucket near the wall' (Iw. 3311)

4 See Nishiwaki (2010, 17-62) on the development of the partitive genitive and its relation to indefiniteness, with further examples from Old and Middle High German. 
(5) MHG

Wand ich noch ein-er salbe-n hân die dâ

because I still a-GEN.F ointment-GEN.F have that there

Feimorgân machte

Feimorgân made

'Because I still have some ointment made by Feimorgân' (Iw. 3423)

(6) MHG

Do rais im $\hat{u} z$ einer swalwen nest des

at.once fell him from a swallow's nest the.GEN.M

mist-es in diu ougen

excrement-GEN.M in the eyes

'Excrement fell on his eyes out of a swallow's nest' (Sermons, 13th c.,

Grieshaber 1844, 128)

This usage of genitive forms continues until Early New High German (ENHG, 1350-1650 AD) times, as (7) exemplifies for a definite article, without referring to a particular piece of bread:

(7) ENHG

Iss des brot-s

eat the.GEN.N bread-GEN.N

'Eat (some) bread' (Luther, OT., Ruth 2.14)

The use of genitive-marked determiners in order to express part-whole relations had its parallel in the use of genitive pronouns in cases of pronominalization, as the following selected examples with demonstrative and personal pronouns show. All three examples contain a pronoun with anaphoric reference to a neuter noun, brot 'bread' in (8), swinâz 'pigfeed' in (9) and holtz 'wood' in (10), the latter in subject position:

(8) OHG

nam er tho selbo thaz brot [...] gibot thaz sie-s took he then himself the bread [...] demanded that they-it.GEN azin

ate.sBJV

'then he took the bread and demanded that they should eat it/some' (O. 4.10.9) 
(9) MHG

und dez gap im nieman

and this.GEN gave him nobody

'and nobody gave him any' [pigfeed] (Sermons, 13th c., Grieshaber 1848, 78)

(10) ENHG

darmit das holtz, ob im des zufluß, aus dem

with.this the wood if him this.GEN towards.flowed out.of the

wasser gezogen werd

water pulled was

'so that he could pull the wood flowing towards him out of the water' (ms. 1475, Lexer 1862, 250)

We will not further elaborate on these historical examples of pronominal constructions. With regard to the further development, however, we can state that in several Germanic varieties the pronominal partitive genitive continues to exist much longer (see Glaser 1992, Strobel 2017) than the nominal genitive in partitive function.

It is during the Early New High German period that the partitive use of the nominal genitive gradually becomes rarer. A process of case loss concerning genitive case is going on, not only affecting the independent as well as dependent partitives discussed here but also other adverbal uses (Reichmann and Wegera 1993, 330-334, 353; Scott 2014, 225). Although there is no consensus on the exact motivation for the substitution of genitive case by accusative or even nominative forms, there is no doubt that the decline of the genitive case necessarily led to the loss of the possible expression of partial use in independent constructions (Fleischer 2011, 87-94). The usage of the genitive forms with true partitives and pseudo-partitives continues for a longer time, as documented for instance in several Early New High German cook books containing many partof and measuring expressions, both with an article (11a) or without (11b), often dependent on quantifiers such as viel 'much' (11) or other quantifying nouns (12):

(11) ENHG

a. reibe [...] ein-es so viel als deß ander-n grate $[\ldots]$ one-GEN.M/N as much as the.GEN.M/N other-GEN.M/N 'grate from one [mass nouns M. and N.] as much as from the other' (1691, Stopp et al. 1980, 123) 
b. nim II mal als uil Johannestreiblin als zugger-s

take two times as much redcurrant as sugar-GEN.M

'take twice as much redcurrant as sugar' (ms. 16th c., Letsch 2018, nr. $115)$

(12) ENHG

a. 3 seydla wein-s

three mugs wine-GEN.M

'three mugs of wine' (ms. around 1550, f. 116r) $)^{5}$

b. nim deß schönst-en zucker-s $\quad 1 / 2 \quad l b$

take the.GEN.M finest-GEN.M sugar-GEN.M half pound

'take half a pound of the finest sugar' (ms. 1640, 167 $)^{6}$

Even in New High German (NHG, 1650-AD), it is possible to use the dependent partitive genitive in formal contexts or archaic speech, especially together with an adjective. ${ }^{7}$

(13) NHG

ein Glas kühl-en Wein-es

a glass chilled-GEN.M wine-GEN.M

'a glass of chilled wine'

In nearly all recent dialects, the genitive forms have died out, both with nouns and determiners. However, there are still some varieties of Continental West Germanic such as Luxembourgish (cf. e.g., Christophory 1974; Schanen and Zimmer 2006; Döhmer 2017, 2018) or Walliser and Walser German dialects (Henzen 1932, 122-124; Szadrowsky 1937, 278-279, 281, 284; 1940) where we can find remnants of the older genitive markers expressing (pseudo-)partitivity or similar functions. We will now take a closer look at the formation, distribution

5 Our thanks go to Mathias Wolfbeiss, Augsburg, for leaving us the unpublished transcription of the Pharmacopoeia manuscript, the so-called Arzneibuch der Philippine Welser (Wien, Kunsthistorisches Museum Inv.Nr. PA 1474).

6 This example is taken from the transcription in Müller (2010, 169).

7 It is not surprising that this case of still not fully completed language change leads to a grammatical doubt (Zweifelsfall) with (native) speakers of contemporary German, concerning the use of a partitive genitive as in ein Glas kühlen Weines (a glass chilled wine-GEN) vs. an apposition as in ein Glas kühlen/kühler Wein (a glass chilled wine-ACC/NOM) for 'a glass of chilled wine' (cf. e.g., Hentschel 1993; Zimmer 2015). 
and semantics of noun phrases containing a partitive genitive in these varieties, especially at so-called "partitive determiners".

\section{The Situation in Modern (West) Germanic Varieties}

The following results go back to recent questionnaire elicitations and fieldwork on "partitive markers" - determiners as well as pronouns-in Walliser German dialects (Highest Alemannic) and Luxembourgish (Moselle Franconian), with about 40 test sentences (and their variants) and a total of more than 30 informants from different places. ${ }^{8}$ The aim of our investigation was a detailed analysis primarily of noun phrase structures with partitive determiners with respect to

(i) case marking for genitive/partitive within the noun phrase,

(ii) the type and form of the determiner (its choice in compliance with countability, number and gender),

(iii) their independence vs. dependence of quantifying expressions,

(iv) the different interpretations or readings of these constructions.

As has been reported previously, there are two morphological forms of the partitive determiner in Luxembourgish: one for plural and feminine mass nouns, där (with the variants deer, därer etc.), as in (14a) for plural Äppel 'apples' and (14b) for feminine Mëllech 'milk', and another one for masculine and neuter mass nouns, däers (or dees, däs, därs, däres etc.), as the sentences in (14c) and (14d) show for masculine singular Téi 'tea' and neuter singular Gas 'gas', respectively. Apart from a few geographical and orthographic variants to these forms, the basic system remains the same. Note that the head nouns of the partitive

8 In the 2018 main inquiry (July-October), we used partially identical written questionnaires for Walliser German and Luxembourgish with the main difference that we left out the translation tasks directed to the use of nominal genitive forms in Luxembourgish, as Luxembourgish has lost these case forms, whereas in Walliser German they are still in use depending on various criteria. Moreover, we inserted several translation tasks containing French sentences with "partitive articles" in the Luxembourgish questionnaire, in order to see if the French model leads to a corresponding Luxembourgish equivalent. For the rest, we relied on question types and tasks repeatedly used in dialect syntactic projects on German dialects (see Glaser and Bart 2015; Lenz, Fleischer and Weiß 2015; Weiß and Strobel 2018), namely a combination of grammaticality judgment tasks (multiple choice) for various constructions possibly showing the use of genitives in the nominal group and translations from Standard German. In fall 2017, we had started a pilot study in the Wallis with several grammaticality judgment tasks in order to identify regional variation in the use of the different determiners analyzed in our present study. 
phrases, however, are not marked for genitive, since case marking is completely lost in Luxembourgish.

(14) a. Hu mer nach där Äppel?

have we still the.GEN.PL apples

'Do we still have (some) of these apples?' (Döhmer 2017, 105)

b. Ech hätt gären där Mëllech

I had gladly the.GeN.F.SG milk

'I'd like (some) milk of this kind.' (LWB, vol. 1, col. 193b)

c. Hu mer nach däers Téi?

have we still the.GEN.M.SG tea

'Do we still have (some) of this tea?' (Döhmer 2017, 105)

d. geologesch Schichten, wou däers Gas ze fannen ass geological strata where the.GEN.N.SG gas to find is 'geological strata where one can find (some) of this gas' (Döhmer 2017, 117)

The quoted independent partitive noun phrases — dependent partitives with a numeral/quantifier or a measure phrase will be discussed later-have different syntactic functions, representing the direct object in $(14 \mathrm{a}-\mathrm{c})$ and the subject in (14d). This construction, however, seems to be ungrammatical in indirect object position (15a) and after prepositions (15b), as Döhmer (2017) points out. This finding is confirmed by our data, where both test sentences did not provide any instance of a partitive determiner (instead, our informants almost consistently used (mat) sou Leit, i.e., 'so/such', in these contexts). ${ }^{9}$
(15) a. *Ech vertrauen där
Leit net
I trust the.GEN.PL people not
'I don’t trust such (lit. of these) people.' (Döhmer 2017, 127)

9 However, we found an example of a (neuter singular) noun phrase introduced by a partitive determiner selected by a preposition on the internet: Mat däers knaschtgem Geld, wat sténkt? 'With such dirty money, which stinks?' (https://www.josychristen.lu/gedichter/einfach-esou/ de-secret-vu-lëtzebuerg). 


\section{b. *Mat där Leit ginn ech net eens} with the.GEN.PL people go I not okay 'With such (lit. of these) people, I don't get along.' (Döhmer 2017, 127)

As for Walliser German, we can find some older examples of partitive determiners in the literature. ${ }^{10}$ Henzen (1932) reports various partitive structures from the Lötschental dialect of the early 2oth century, hardly discussing, however, their function compared to bare nouns (cf. Martin, Carvalho and Alexiadou, this volume, for a discussion of bare nouns in subject position). The independent partitive noun phrases in (16) and (17), respectively, show different genitive forms of the determiner in the plural, $d \ddot{a} r(u)$ and dischr, the second one being clearly a demonstrative pronoun. Note that the noun phrases in (16b-c) have a kind of-reading ('such'), example (16c) is the only one displaying subject position and the noun phrases in (16c) and (17) are additionally modified by an adjective chlein 'small'. The example in (18), also taken from Henzen (1932) and containing the same adjective, illustrates that the partitive genitive, marked by the determiner dera, was also present in Walser dialects, for example, in Davos (Grisons). Interestingly, most of these older examples-except for (16b) and (18) - are marked for genitive not only on the determiner but also on the head noun.

(16) a. weldr den däru schtein-u? want.you then the.GEN.PL stones-GEN.PL 'do you want (some) of these stones?' (Henzen 1932, 122)

b. däru biähär hetti miär schōn oich the.GEN.PL books would.have we even also 'we do also have (some) of these/such books.' (Henzen 1932, 122)

c. Där chlein-u schäfflin-u $\quad[\ldots]$ di heind nuch the.GEN.PL small-GEN.PL sheep-GEN.PL [...] they have still wēnig wollu

little wool

'Such small sheep do still have little wool.' (Henzen 1932, 104-105)

10 The following examples taken from the dialectological literature are transliterated in a slightly simplified manner here, by avoiding special characters. 
(17) Dā gänd sch na disch-r chlein-um biks-u there give they you these-GEN.PL small-GEN.PL cans-GEN.PL 'There they give you (some) of these small cans.' (Henzen 1932, 122)

(18) $[$ er] heiga [...] dera chleina tannalti uss da würza [he] has.SBJV [...] the.Gen.PL small fir.trees out.of the root grissa pulled.up 'he has pulled up (some) of these small fir trees together with their roots.' (Henzen 1932, 123)

In modern Walliser German dialects, genitive forms with partitive function are still present, but with some important changes and a great deal of variation, which is typical for processes of disintegration and language change. The most common forms we encounter are deru (or dero/-ä/-e, därru) and deschi (or desch), constituting quite different systems, though, most frequently with a split between plural and mass nouns. In (19)-(20), the present-day systems are illustrated by examples for independent partitive genitive constructions from the main valley (Visp and surroundings), taken from our questionnaires (main inquiry). The informant in (19) used deru for plural (Epfla 'apples'), whereas deschi appeared in combination with mass nouns, feminine (Milch 'milk') as well as masculine (Kaffe 'coffee'). Another informant, see (20), accepted both forms deru and deschi with plural and feminine singular (Epfla 'apples' and Milch 'milk'), but only deschi together with masculine and neuter singular (Kaffe 'coffee' and Bier 'beer'):

(19) a Welltisch nu deru Epfla? want.you more the.GEN.PL ${ }^{11}$ apples
b. Welltisch nu deschi Milch? want.you more the.GEN.SG milk

11 Apart from etymologically unambiguous demonstratives (see our comment on example 17), we decided to gloss partitive determiners such as deru and deschi uniformly as genitive forms of the definite article, because a formal distinction to the so-called simple demonstrative forms is impossible in German. In cases of deictic use, however, we use a demonstrative in the English translation. 
c. Welltisch nu deschi Kaffe? want.you more the.GEN.sG coffee 'Would you like (some) more of these apples/of this milk/of this coffee?' (Gampel/Visp_1944)

(20) a. Welltisch nu deru/deschi Epfla? want.you more the.GEN.PL apples

b. Welltisch nu deru/deschi Milch? want.you more the.GEN.SG milk

c. Welltisch nu deschi Kaffe? want.you more the.GEN.SG coffee

d. Heider öi deschi Bier? have.you also the.GEN.sG beer 'Do you also have (some) of this beer?' (Visp_1988)

Apart from these test sentences for partitive genitive phrases functioning as direct objects, we included also other syntactic functions, that is, as a subject, an indirect object and after a preposition, in order to compare the results to the restrictions observed in Luxembourgish. Again, the Walliser German data show that we do find partitive nominals in subject position, for example, (21a). Similarly to Luxembourgish, where partitive genitive phrases in indirect object position and after prepositions were completely absent, these cases seem to be quite bad in Walliser German, too. Nevertheless, we got one answer for deru Lit (21b) (with a majority for denu/-e/-ä Lit 'those people' and-in the Lötschental-settigä/däriga Li(i)tn 'such people'), and three informants accepted mit deru/-ä/deschi Lit (21c) (many more, though, mit settige/-ä Lit(n) 'with such people'). ${ }^{2}$

(21) a. Deru chleini Firmä hent sus mit der hitig the.GEN.PL small businesses have it with the today's

12 Another proof for a noun phrase with a partitive determiner after a preposition (and the expansion of dèru to neuter mass nouns) comes from Bosco Gurin (Walser German in Ticino): un tås Broot heind-sch aba met dèru Maal [...] un hein Puleantu ggmåchut [...] (Gerstner-Hirzel 1979, 13) 'and they have the bread exactly with such flour [...] and made polenta $[\ldots]$. 
Konkurränz nit einfach

competition not easy

'Such small businesses don't have an easy time because of today's competition.' (Gampel/Visp_1944)

b. Ich vertrüwwu deru Lit nit

I trust the.GEN.PL people not

'I don't trust such people.' (Gampel/Visp_1944)

c. Mit deru/-̈̈/deschi Lit chumi nit zrächt

with the.GEN.PL people come.I not alright

'With such people I don't get along.' (Gampel/Visp_1944, Staldenried_ 1949, Lalden_1988)

A pretest (fall 2017) on the distribution of the two forms deru (dere) and deschi with respect to number and gender of the head noun provided us with the (schematized) results in Table 2.1, which outlines the situation for three places or areas in the Upper Valais (from East to West): Goms, Visp and Guttet-Feschel. The choice of the respective partitive determiner was tested for plural, feminine mass nouns and masculine/neuter mass nouns. The syntactic contexts covered independent as well as dependent partitive genitives and both noun phrases with and without attributive adjectives. Note that besides the use of "partitive articles", bare nominals or a null determiner were almost always possible, giving rise to a different, non-partitive meaning, though (cf. Giusti, this volume, for a comparison of five indefinite determiners, including the "partitive article" and the null determiner, and their distribution in Italian and ItaloRomance).

These results for partitive determiners in Highest Alemannic in combination with the situation in Luxembourgish reveal that we need to distinguish at least four different systems, a finding that basically has been confirmed and could be refined in our main inquiry. The first system holds for Luxembourgish, behaving very consistently in this respect, the second one is the most frequent for Walliser German, where we find considerable variation, though:

- PL/F.SG: där (därer)—M./N.SG: dä(e)rs (dees) (Luxembourgish):

This first system makes a morphological distinction between plural and feminine singular on the one hand and masculine/neuter singular on the other. This corresponds to the original clustering and is analogous to the different forms of partitive pronouns still to be found in the same varieties, among others. 
TABLE 2.1 Distribution of partitive determiners in Walliser German in terms of number and gender (pretest October 2017)

\begin{tabular}{|c|c|c|c|c|}
\hline & & Goms & Visp & $\begin{array}{l}\text { Guttet- } \\
\text { Feschel }\end{array}$ \\
\hline \multirow[t]{2}{*}{ PL } & $\begin{array}{l}\text { Welleder nu deru/deschi } \\
\text { Steina/Boone/Epfla? } \\
\text { 'Do you still want (some) } \\
\text { of these stones/beans/apples?' }\end{array}$ & $\begin{array}{l}\text { dere } \\
* \text { deschi } \\
\varnothing\end{array}$ & $\begin{array}{l}\text { deru } \\
\left(^{*}\right) \text { deschi } \\
\varnothing\end{array}$ & $\begin{array}{l}\text { deru } \\
* \text { deschi } \\
\varnothing\end{array}$ \\
\hline & $\begin{array}{l}\text { Hets nu e Hampfleta } \\
\text { deru/deschi Boone? } \\
\text { 'Is there still a handful } \\
\text { of these beans?' }\end{array}$ & $\begin{array}{l}\text { dere } \\
{ }^{*} \text { deschi } \\
\varnothing\end{array}$ & $\begin{array}{l}\text { deru } \\
\text { deschi } \\
\varnothing\end{array}$ & $\begin{array}{l}\text { deru } \\
{ }^{*} \text { deschi } \\
\varnothing\end{array}$ \\
\hline F.SG & $\begin{array}{l}\text { Welleder nu deschi (güeti/waarmi) / } \\
\text { deru Milch? } \\
\text { 'Do you still want (some) } \\
\text { of this (good/warm) milk?' }\end{array}$ & $\begin{array}{l}\text { *deru } \\
\text { deschi } \\
(\varnothing)\end{array}$ & $\begin{array}{l}\text { *deru } \\
\left({ }^{*}\right) \text { deschi } \\
(\emptyset)\end{array}$ & $\begin{array}{l}\text { deru } \\
{ }^{*} \text { deschi } \\
(\varnothing)\end{array}$ \\
\hline M./N.SG & $\begin{array}{l}\text { Welleder nu deschi (güeta) / } \\
\text { deru (schwarzu) Kaffe? } \\
\text { 'Do you still want (some) } \\
\text { of this (good/black) coffee?' }\end{array}$ & $\begin{array}{l}{ }^{*} \text { deru } \\
\text { deschi } \\
(\varnothing)\end{array}$ & $\begin{array}{l}\text { *deru } \\
\left({ }^{*}\right) \text { deschi } \\
(\emptyset)\end{array}$ & $\begin{array}{l}\text { deru } \\
* \text { deschi } \\
(\varnothing)\end{array}$ \\
\hline
\end{tabular}

- PL: deru (dero/-ä/-e)—MASs: deschi (Valais: Pretest Goms, Eyholz_1962, Lalden_199o, Staldenried_1949 etc.):

A second system seems to have generalized the original masculine/neuter singular form to all mass nouns, using it also for feminine singular. This has led to a new opposition between plural and mass nouns (apart from a few outliers leading to mixed systems). As to their pronominal counterparts, on the one hand we find the old split between plural/feminine singular $(r a / r u / d e r u / d \ddot{r}$, but for feminine singular also deschi) and masculine singular (innovative null anaphora) (here: Eyholz_1962) — with an interesting dissociation between partitive determiners and pronouns - and, on the other hand, a corresponding, symmetric configuration of plural (deru/-o) vs. mass (deschi) (e.g., Staldenried_1949).

- PL: deru/deschi-MASS: deschi (Valais: Pretest Visp, Lalden_1988, Brig 1960):

In a third system, the original masculine/neuter singular form has not only been extended to all mass nouns, but it has also entered the plural, where it 
coexists with the original plural form. In a slightly different subsystem, characterized by the distribution PL/F.SG: deru/deschi-M./N.SG: deschi (e.g., Visp_1988), this change has not gone so far in the feminine singular, yet, since, as in the plural, deschi has not replaced completely deru here neither. The opposite development towards a system of PL: deru-MASS (N.SG): deschi/deru, with an expansion of deru instead, could be the case for Brigerbad_1986.

- PL \& mass: deru (no deschi) (Valais: Pretest Guttet-Feschel, Ticino: Bosco Gurin $\left.{ }^{13}\right)$ :

Another pathway can be identified in a fourth system, which has just one single form left, irrespective of number and gender, as a result of having totally generalized the original plural/feminine singular form.

This means that the partitive determiners in Walliser (and Walser) German underwent a change away from the original distribution of number- and gender-specific forms (PL/F.SG vs. M./N.SG) towards more syncretic forms. Despite this attempt to systematize the picture, however, there are still a lot of cases where deru and deschi seem to appear in almost completely mixed systems (PL: deru/deschi-MASs: deschi/deru).

Considering the above discussion on syncretisms and mixed systems in the nominal domain, one question that arises is whether there is a correspondence between the nominal and the pronominal domain or whether the former parallelism has been broken up. Note that in our Alemannic dialects-in contrast to Luxembourgish-, the potentially competing strategy of a null anaphora $(\varnothing)$ has to be taken into account on the pronominal side (cf. e.g., Glaser 1993, 1995, 2008; Strobel 2017). Our recent elicitation of Walliser German has shown that this innovative strategy is still rare in comparison to the older genitive pronouns when referring to plural terms and feminine mass nouns, but that it is already the predominant strategy with masculine and neuter mass nouns, being up to twice as frequent as the genitive pronoun in this case. ${ }^{14}$ With

13 In Bosco Gurin (Walser German) we found uniformely deru or deschru both for plural and mass nouns. Our informants clarified that deru was used for something further away and deschru for something nearby the speaker, having thus a demonstrative character (fieldwork October 2018).

14 The respective numbers of occurrence (null anaphora vs. genitive pronoun) show the following distribution:

- PL (Pilza 'mushrooms', fü̈̈ Gschwisterti 'five siblings'): $1 \varnothing$ vs. $17 \mathrm{ra} / \mathrm{ru} / \mathrm{dru} /$ deru (and 10 occurrences of a genitive pronoun in the test sentence with a stranded numeral)

- F.SG (Milch 'milk', en Schgutz Milch 'a drop (of) milk'): $3 \varnothing$ vs. $6 \mathrm{ra} / \mathrm{ru} / \mathrm{dra} /$ dära +5 schi/deschi 
respect to the number/gender configuration, there is indeed a certain equivalence of such partitive pronouns to the two main systems identified above:

- PL/F.SG-M./N.SG:

As already mentioned, this conservative clustering holds for Luxembourgish with the forms der (weak) and där/därer (strong) for plural and feminine mass nouns vs. es (weak) and däers/dees (strong) for masculine and neuter mass nouns (see also Döhmer 2017). Moreover, we still find this split in a few Walliser German dialects or idiolects, distinguishing for instance between ru/deru and deschi/ $\varnothing$ (Gampel/Visp_1944) or $r a / r u$ and $\varnothing$ (Visp_1988) for plural and feminine singular on the one hand and masculine/neuter singular on the other, where zero marking has already made its way into both systems.

- PL-MASS:

Other systems of pronominal partitivity in Walliser German show a split between plural terms and mass nouns, either as $r a / r u / d e r u /-o$ vs. schi/deschi (Lalden_2003, Brigerbad_1986, Staldenried_1949) or as $r a / r u$ vs. deschi/ $\varnothing$ (Brig_1960) or else as $r a / r u / d r u / d e r u$ vs. $\varnothing$ (Agarn_1996, Staldenried_1982), reflecting also a different degree of progression of the innovative null anaphora (which, according to the "apparent-time hypothesis", cf. e.g., Chambers and Trudgill 1998, becomes evident also on an intergenerational level in view of the dates of birth of the two informants from Staldenried).

Apart from these two principal patterns, some dialectal/idiolectal systems of partitive anaphors in the Valais appear to be quite chaotic — especially younger speakers seem to be rather insecure (cf. e.g., Lalden_1993: $r u$ for plural and neuter singular, deschi for feminine and masculine singular, but also $\varnothing$ for masculine singular)—, which, again, is typical for restructuring and decomposition processes. Furthermore, the finding that partitive pronominals seem to survive longer than the corresponding determiners becomes apparent in a striking way in the (often more conservative) Lötschental, where we do not find any partitive genitive determiners anymore, but still partitive genitive pronouns (mostly $d r u / d r a$ for plural/feminine mass nouns vs. schi/däschi or $\varnothing$ for masculine and neuter mass nouns).

(and $1+2$ occurrences of a genitive pronoun in the test sentence with a residual quantifier)

- M.SG (Zucker 'sugar', es Glas Wii 'a glass (of) wine'): $11 \varnothing$ vs. 5 schi/deschi (and 7 occurrences of a genitive pronoun in the test sentence with a residual quantifier)

- N.SG (Gääld 'money'): $8 \varnothing$ vs. 4 schi/deschi + marginally 1 ru 


\subsection{Case Marking for Genitive/Partitive}

If one takes a closer look at the entire partitive noun phrase structure, one can notice both for modern Walliser German and Luxembourgish that genitive case is only marked on the determiner, not on the head noun itself (see already Szadrowsky 1940), ${ }^{15}$ clearly missing the characteristic genitive $-s$ inflection for masculine/neuter singular. This is exemplified again in (22) and (23), respectively: ${ }^{16}$

(22) Valais

a. Welltisch nu deschi Kaffe- $\varnothing$ ? want.you more the.GEN.sG coffee- $\varnothing$ 'Would you like (some) more of this coffee?' (e.g., Visp_1988)

b. Heider öi deschi Bier- $\varnothing$ ? have.you also the.GEN.sg beer- $\varnothing$ 'Do you also have (some) of this beer?' (e.g., Visp_1988)

(23) Luxembourgish

a. Wëllst du dä(e)rs (dote) Kaffi- $\varnothing$ ? want you the.GEN.sg (there) coffee- $\varnothing$ 'Do you want (some) of this/that coffee (there)?' (e.g., LuxemburgStadt_1946)

b. Hutt dir därs (dote) Béier- $\varnothing$ ? have you the.GEN.sG (there) beer- $\varnothing$ 'Do you have (some) of this/that beer (there)?' (e.g., Luxemburg-Stadt_ 1946)

This fact forms a clear contrast to the historical examples from the Old, Middle and Early New High German periods, see sentences (1)-(7) in Section 2,

15 Szadrowsky (1940, 232) emphasizes the missing genitive ending in constructions such as désch Häu häi-mr rächt gnueg 'we have really a lot of this hay' in the Grisons Walser dialect of Klosters. The loss of genitive marking on the noun, leaving behind solely the determiner in a frozen genitive form, is already attested in Brandstetter (1904) for Lucerne. For further information on comparable data in West Central German and other dialects see Weise (1906, 294-295).

16 In total, we got one single instance of a genitive suffix on the noun (-sch) in our entire elicitation: Hets nu deschi güetä Wiisch? 'Is there still (some) of this good wine?' (Valais: Lalden_1990). 
where both the determiner and the noun were marked for genitive: for example, OHG thes wines (the-GEN wine-GEN), thes unazares (the-GEN water-GEN); MHG des mistes (the-GEN excrement-GEN), eines wazzers (a-GEN water-GEN); ENHG des brots (the-GEN bread-GEN). It seems that this rule was still valid for some Walliser dialects at the beginning of the 2oth century, see some of the (plural) examples in (16)-(17), so that we can assume a recent language change.

However, in partitive noun phrases containing a modifying adnominal adjective, genitive case is additionally marked on the adjective. This is true both for Walliser German (24) and Luxembourgish (25), where the -er suffix on the adjective after the determiner där is a specific genitive ending. Note the apparent case difference for the Walliser German dialects, though: while the adjectives siess 'sweet' and schwarz 'black' display a genitive ending - $u$ after the determiner deru, siess 'sweet' and güet 'good' have accusative morphology after deschi instead ( $-i$ and $-a$, respectively), governed by the verb welle 'to want'.

(24) a. Valais: Visp

Welleder nu deru siess-u Boone / deschi siess-i want.you more the.GEN sweet-GEN beans the.GEN sweet-ACC

Boone?

beans

'Would you like (some) more of these sweet beans?'

b. Valais: Guttet-Feschel/Goms

Welleder nu deru schwarz-u Kaffe / deschi güet-a want.you more the.GEN black-GEN coffee the.GEN good-ACC

Kaffe?

coffee

'Would you like (some) more of this black/good coffee?'

(25) Luxembourgish

Et leet een dann där kleng-er Steng dohinner

it puts one then the.GEN.PL small-GEN.PL stones there

'Then, one places such small stones there.' (Döhmer 2017, 129)

The results from our exploration are in line with the description of the Luxembourgish adjectival inflection after partitive determiners by Döhmer (2017). She points out that the adjective bears an -er suffix for plural (där kleng-er Betriber 'of these/such small businesses') and feminine singular (därgudd-er Mëllech 'of this good milk') as well as an -en ending for masculine (däers gudd-en Hunneg 'of this good honey') and neuter singular (dëers deier-en Holz 'of this expen- 
sive wood'). Besides noun phrases such as där(/därer) séisser Kiischten 'of these sweet cherries' and där waarmer Zopp 'of this warm soup', which correspond to the expected pattern där $\mathrm{A}$ (djective)-er $\mathrm{N}$ (oun) for plural/feminine singular, in our questionnaires, however, we marginally got also adjectives without an ending (in total 3 times där séiss Kiischten). The same is true for masculine/neuter singular, where one informant each filled in dëersfrësch Brout (without an ending), däers frëscht Brout (with $-t)^{17}$ and däers frësches Brout (with -es, potentially influenced by Standard German), apart from däers(/dees) frësche Brout 'of this fresh bread' and däers(/dees) gudde Kuch 'of this good cake' in accordance with the main pattern däers A-en $\mathrm{N}^{18}$

As to Walliser German, on the other side, we found competition of especially two adjectival suffixes in the plural (deru(/-o/därru) A-u/-i N: e.g., deru siessu/-i Chriese 'of these sweet cherries', as opposed to unvarying deschi A- $i$ $\mathrm{N}$ : e.g., deschi siessi Chriese), but mostly uniform adjective endings in partitive noun phrases with feminine (deschi A- $i \mathrm{~N}$ : deschi heissi Suppa 'of this hot soup'), masculine (deschi A-e/-ä N: deschi güete/-ä Wii 'of this good wine') and neuter (deschi A-us N: deschi frischus Brot 'of this fresh bread') mass nouns (keeping in mind the variability in using the determiners deru and deschi, respectively). ${ }^{19}$

\subsection{Type and Form of the Determiner}

Concerning the type and form of the determiner introducing our partitive structures, we find a reduction of the possible types from Old High German to the modern varieties. In Old and Middle High German, every type of determiner can be used in the genitive form, that is, definite articles (e.g., OHG thes wines the-GEN wine-GEN, thes unazares the-GEN water-GEN; MHG des mistes the-GEN excrement-GEN; ENHG des brots the-GEN bread-GEN) and indefinite articles (MHG eines wazzers a-GEN water-GEN) as well as demonstratives or

17 For the $t$-suffix on the adjective with neuter see also an example from the literature: mam gudde Riecher fir déi richteg Plazen, wou däers "schwaarzt Gold" op eis kéint waarden (LuxBintner 2014, 16) 'with a good feeling for the right places, where such "black gold" could wait for us'.

18 The $n$-loss of the adjectival suffix -en in these examples is due to the so-called "Eifeler Regel" (Eifel Rule), which is typical of Luxembourgish and some West (Central) German varieties.

19 For instance, we had a slight prevalence of deschi over deru in the dependent partitive structure en Hamfleta deschi grieni Boone 'a handful of these green beans' - a finding that cannot be generalized to all dependent partitives, however-, whereas in the cited IPG deru siessu/-i Chriese 'of these sweet cherries' the form deru occurred much more often. 
possessives (OHG iunares oles your-GEN oil-GEN). In the modern varieties, however, we only find specific elements used to form nominal partitive constructions, former demonstratives and partly new formations such as däers with unclear etymology in Luxembourgish: där Äppel 'of these apples', däers Wäin 'of this wine'. In the Valais, we have various forms of the d-pronouns deru and deschi (the latter one being explained as $<$ des $+\sin$ ): 20 deru Boone 'of these beans', deschi Kaffe 'of this coffee'.

There are some Continental Germanic varieties, though, where the loss of the genitive gave rise to new markers or a reuse of forms, with the result that another type of nominal partitive developed, namely a periphrastic construction using the preposition von/van 'from, of' selecting a plural or mass noun phrase with different determiners (and, if applicable, marked for dative case). This "von/van-periphrasis" used as-among others-partitive expression can be found in some western varieties of German such as Southern Rhine Franconian as well as in Dutch, known there as "faded partitive construction" or "verbleekte partitieven" (cf. e.g., De Hoop 2003; Oosterhof 2005; also Broekhuis and Den Dikken 2012, 625-629, who show that this kind of van-phrase can be used with the distribution of a DP despite its appearance of a PP). It occurs both in independent and dependent constructions, in object and subject position (26)-(27). In both varieties, we have a more or less developed system of at least optional nominal partitivity marking. Dutch does also have partitive or quantitative pronouns (cf. e.g., Luraghi and Kittilä 2014, 23), Southern Rhine Franconian instead has a quite newly developed system of zero marking or null anaphora (cf. i.a. Glaser 1992).

(26) Southern Rhine Franconian

a. Des sin doch fun daine Schdudende?

this are after.all of your students

'These are some of your students, aren't they?'

b. Dissjor hämmer fun de Tomate gstoole griecht this.year have.we of the tomatoes stolen got 'This year we got some of the tomatoes stolen.'

$20 \quad$ Dešš is explained in Bohnenberger $(1913,221)$ as a compound pronominal form consisting of the simple demonstrative deš + ši (possessive pronoun M.SG) (see also fn. 11). The form is mentioned in other dialect descriptions as a demonstrative pronoun, see Wipf (1910, 142-143). 
(27) Dutch

Er lagen van die dikke boeken op de tafel there lay of those thick books on the table 'Some thick books lay on the table.' (Luraghi and Kittilä 2014, 23)

The Algemene Nederlandse Spraakkunst (ANs, Haeseryn et al. 1997) labels the Dutch van+demonstrative-construction as informal and points to a differentiation between proximal (van deze/van dit (soort) as in van deze pennetjes 'of these pens' or van dit glas 'of this glass') and distal (van die/van dat (soort) as in van die chocola 'of that chocolate' or van dat fijne zand 'of that fine sand'), depending on the type of demonstrative determiner (see E-ANs: http:// ans.ruhosting.nl/e-ans/05/o6/og/body.html). The special meaning of this vanconstruction, according to the ANS, often can be paraphrased as 'such ... as you see here in front of you/as we are talking about' or '... you know', with a different intonational structure.

In Walliser German, too, in many instances it is possible to exchange the genitive phrases by a prepositional phrase with $v a$ 'from, of' and a following determiner, see (28) for all varieties of our pretest. This construction seems to have spread in the last decades, as our questionnaires show. It is also possible to have a bare noun here, but a combination of $v a+$ deru/deschi is excluded. Furthermore, the construction appears also in dependent (pseudo-)partitive structures (such as e bitz va dischum Kaffe 'a bit of this coffee', e Schgutz va der Milch 'a drop of the milk' or e Hampfleta va dischu Boone 'a handful of these beans').

(28) Valais: Goms, Visp, Guttet-Feschel

a. Hets nu va denu/-e/dischu/-e Boone?

has.it still of the/these beans

'Are there still (some) of the/these beans?'

b. Hets nu va der/discher Milch?

has.it still of the/this milk

'Is there still (some) of the/this milk?'

The reuse of the preposition vun 'from, of' in partitive constructions can also be found in Luxembourgish, see (29). However, according to our elicitation, it seems that the partitive determiners are still very present and productive there, they have a stronger position than in Walliser German. Moreover, as (30) shows, both topicalized noun phrases with a partitive genitive determiner-in example (30a) with an additional stranded numeral zéng 'ten' - and vun-phrases 
could feature a (resumptive) partitive genitive pronoun in our Luxembourgish data (see also Section 3.3).

(29) a. Wëllst du där (doter) Äppel / vun denen Äppel? want you the.GEN.PL (there) apples of these apples 'Do you want (some) of these/those apples (there)?' (Diekirch_1951)

b. Gëtt et nach däers gudde Kuch / vun deem gudde Kuch? gives it still the.GEN.SG good cake of this good cake 'Is there still (some) of the/this good cake?' (Diekirch_1951)

(30) a. Där Wirschterscher / Vun dene Wirschterscher huet de the.GEN.PL sausages of these sausages has the Michel der zéng giess!

Michel of.them ten eaten

'Michel ate ten of these sausages.' (Esch-sur-Alzette_1986)

b. Vun dene(n) (dote) Beem stin der och bei mir am of these (there) trees stand of.them also at me in.the Gaart garden 'There are also (some) of these/those trees (there)/such trees in my garden.' (Esch-sur-Alzette_1986)

c. Vun deem Opschnatt hu mir es nach doheem of this cold.meat have we of.it still at.home 'We still have (some) of this/such cold meat at home.'(Esch-sur-Alzette -1986)

In many contexts, these markers pattern with functions and the distribution of the so-called "partitive article" in French and Italian. This may also be true for Bavarian dialects, which show a completely different system with an indefinite article used together with mass nouns (31), expressing a partial-affectedness reading (cf. e.g., Kolmer 1999). Bavarian is considered a "radical" article language, nouns being obligatorily accompanied by an article:

(31) a. Hoi a Wossa!

get a water

'Fetch some water!' 


\section{b. I brauchat a Gäid \\ I would.need a money \\ 'I'd need some money.'}

In the history of (especially eastern/southern) High German, the use of indefinite articles with mass nouns is also well documented, see for example (32) from a 16th century cook book manuscript (Sabina Welserin) from Augsburg. The occurrence of these articles is not yet analyzed sufficiently, though. ${ }^{21}$

\section{(32) darnach nim ain rossenwasser}

then take a rosewater

'then take some rosewater.' (ms. 16th c., Stopp 1980, 134)

To mention a last type, we turn to Northern Germanic. As Dahl $\left(2015,5^{\circ}\right.$, 54) reports, there are some Scandinavian dialects in the Peripheral Swedish area, where we find marking of definiteness with mass nouns showing a "nondelimited use", see (33). This (suffixed) definite article obviously can also be considered a partitive marker in the sense of independent partitivity. Although more detailed analyses are lacking, it seems that this kind of independent partitivity marking cannot be compared to the cases mentioned before.

(33) a. Skelletmål (Northern Westrobothnian):

[...] sä skå I väärm mjölka åt 'n

b. Orsa (Ovansiljan):

[...] sö skari wärm mjötje a num

[...] so shall(.)I warm milk.DEF for him

'I'll warm some milk for him.'

Until now, we focused on independent partitives and only sporadically mentioned true partitive and pseudo-partitive constructions-with the latter distinction, however, being often difficult to make without knowing the exact

21 The use of the indefinite article with mass nouns is also known in the modern dialect of Augsburg, representing the East Swabian area next to Bavarian, see Glaser (1995, 7273). A preliminary check of indefinite DPS and PPs in Sabina Welserin's cook book (Stopp 1980) shows that the indefinite article is not obligatory, but it is used in almost half of the instances in the PPS ( 84 out of 177 ) and in $35 \%$ of the cases in the DPS ( 161 out of 460 ), just as in the example cited in the text. 
context. In the next section, we will characterize the situation of these types of dependent partitives.

\subsection{Independent Partitive Genitive (IPG) vs. Dependent Partitives (Partitive and Pseudo-partitive Constructions)}

Apart from the cases of independent partitive genitives discussed (predominantly) so far, that is genitives not directly governed by some head (Lux. där Äppel 'of these apples', däers Béier 'of this beer'; Wall. deru Boone 'of these beans', deschi Kaffe 'of this coffee'), there are also dependent partitives with a numeral/quantifier or a measure phrase (Lux. véier där Wirschterscher 'four of these sausages', ee Glaas däers Wäin 'a glass of this wine'; Wall. e Hampfleta deru Boone 'a handful of these beans', e Schgutz deschi Milch 'a drop of this milk'). ${ }^{22}$ Contrary to Seržant's (2014) assumption, however, the so-called IPG could also be analyzed as dependent on a null element, a non-explicit or nonovert quantifier, which would also make sense in view of the part-whole relation expressed, the undetermined quantity or subset: 'some of (the apples/the beer etc.)'.

In the light of our recent elicitation, it seems that the usage of an archaic partitive genitive determiner in such dependent constructions is less frequent than in the independent examples. In Walliser German, this is especially true for plural noun phrases (3 occurrences of vier deru/deschi Wurschtjini 'four of these sausages', 4 en Hampfleta deru/deschi Boone 'a handful of these beans' and 4 es par deru/deschi Häärpfla 'a few of these potatoes' vs. 7 deru/deschi Epfla 'of these apples'), whereas with mass nouns the (already lower) frequency is the same for IPGs and dependent partitives. Apart from a competing dependent $v a$-phrase (see Section 3.2), we find many instances of simple juxtaposition in these contexts. ${ }^{23}$ In Luxembourgish, the corresponding gen-

22 Similar examples - albeit often in lexicalized expressions - are reported for various Swiss German dialects, for example, in Weber $(1987,140)$ for Zürich German, comprising both independent partitive genitives (S hät dëre Kärli 'There are such guys', S git dëre Toorebuebe 'There are such fools') and dependent ones (vil dëre Lüüt 'many of these people', kä dëre Sache 'none of these things', gnueg dëre Zü̈̈g 'enough of this stuff'), apparently with a generalized dëre in this dialect (see the different systems at the beginning of Section 3).

23 The following Walliser German examples taken from our elicitation illustrate such competing strategies:

- va-phrase: vierva dische/va de/vanu/vane(/va dene) Wurschtjini(/-u) 'four of these/the sausages', en Hampfleta va dische/va de/vanu/va dene Boone 'a handful of these/the beans', es parva dische/va de/vanu/va dene Häärpfla 'a few of these/the potatoes'

- numeral/quantifier + noun: vier Wurtschjini 'four sausages', en Hampfleta Boone 'a handful (of) beans', es par Häärpfla 'a few potatoes' 
itive determiner seems to generally appear less often with dependent partitive structures (9 véier där/därer Wirschterscher 'four of these sausages', 7 ee Schotz där (doter)/därer Bounen 'a bunch of these/those beans (there)', $9 e$ puer där (heiter)/därer Grompere 'a few of these potatoes (here)'; 4 genuch där (doter)/därer Mëllech 'enough of this/that milk (there)'; 3 e bëssen dä $(e) r s$ (dote) Kaff 'a bit of this/that coffee (there)', 5 ee Glaas däers/dees (dote) Wäin 'a glass of this/that wine (there)') than with the independent ones (11 där (doter) Äppel 'of these/those apples (there)', 7 där (doter) Mëllech 'of this/that milk (there)', 7 dä(e)rs (dote) Kaff, 'of this/that coffee (there)') (except for one test sentence, containing the phrase e bëssen där gudder Zopp 'a bit of this good soup'). Here, too, the partitive genitive determiners are in competition with the vun-construction and, even more, with juxtaposition structures. ${ }^{24}$

All in all, Luxembourgish features different possibilities of undetermined and determined noun phrases relevant in our context: bare nouns as in Beispiller 'examples', quantified noun phrases such as zwee Beispiller 'two examples' - these two types correspond to German, English and other Germanic languages. Hence, in Luxembourgish we can have bare indefinite nouns as for instance in (34a), in contrast to French. Furthermore, there are nominals with a partitive determiner: IPGS as in där Beispiller 'of these examples' on the one hand, see (34b), and dependent partitives as in honnert där Beispiller '100 of these examples' on the other hand, see (34c) (examples from Döhmer 2017, 120-121):

(34) a. Gitt Beispiller!

give examples

'Give examples!'

\section{b. Mir hunn all Dag där Beispiller}

we have every day the.GeN.PL examples

'Every day we have (some) of these examples.'

24 These are some examples of such alternative constructions used by our Luxembourgish informants:

- vun-phrase: véier vun dene( $n$ dote) Wirschterscher 'four of these/those sausages (there)', ee Schotz vun dene Bounen 'a bunch of these beans', e puer vun dene Grompere 'a few of these potatoes'; genuch vun der Mëllech 'enough of this milk'; e bësse vun deem/vum Kaffi 'a bit of this/the coffee', ee Glaas vun deem Wäin 'a glass of this wine'

- numeral/quantifier + noun: véier Wirschterscher 'four sausages', ee Schotz Bounen 'a bunch (of) beans', e puer Grompere 'a few potatoes'; genuch Mëllech 'enough milk'; $e$ bësse Kaffi 'a bit (of) coffee', ee Glaas Wäin 'a glass (of) wine' 


\section{c. An ech kéint nach 100 där Beispiller nennen and I could more 100 the.GEN.PL examples mention 'And I could mention 100 more of these examples.'}

Together with a quantifying expression, we find several possibilities for the position of the numeral/quantifier or measure phrase of the partitive noun phrase, exemplified here by the attested positional variants in Luxembourgish. According to our elicitation, though, this is in principle also applicable to Walliser German. In the examples under (35), we can see the "normal" starting structure with a prenominal position of the quantifier within the noun phrase (véier där Wirschtercher 'four of these sausages', e puer där Kostümer 'a few of these costumes'):

(35) a. Ech hu véier där Wirschtercher giess

I have four the.GEN.PL sausages eaten

'I ate four of these sausages.' (LOD: där)

b. Et ginn e puer där Kostümer

it gives a few the.GEN.PL costumes

'There are a few of these costumes.' (Döhmer 2017, 127)

In (36), in contrast, the DET $+\mathrm{N}$ constituent has been moved to the left of the quantifying phrase, but still remains within the nominal domain (däers Waasser vill '(lit.) of this water a lot', där Billercher eng Hellewull '(lit.) of these pictures loads of' $): 25$

(36) a. Mir brauchen däers Waasser vill

we need the.Gen.sg water much

'We need a lot of this water.' (Döhmer 2017, 126)

b. Mäi Papp huet där Billercher eng Hellewull an engem my dad has the.Gen.PL pictures a load in a Album album

'My dad has loads of these pictures in an album.' (Jhemp Hoscheit: Perl oder Pica)

25 Together with the negation element net 'not' or adverbs such as gär (in Ech hätt gär ... 'I'd like (to have) ...'), see for instance Mir/Mer hunn där Wippercher/däers Wäin net genuch 
In (37), eventually, we get a discontinuous noun phrase by extraction, which reminds of Split-Topicalization or Floating Quantifiers (Deer Täertercher ... eng '(lit.) Of these tartlets ... one', Där Wippercher ... (net) genuch '(lit.) Of these sausages ... (not) enough'):

\section{(37) a. Deer Täertercher wëll ech eng}

the.GEN.PL tartlets want I one

'I want one of these tartlets.' (Schanen and Zimmer 2006, 90)

\section{b. Där Wippercher hu mer net genuch}

the.GEN.PL sausages have we not enough

'We don't have enough of these sausages.' (http://www.land.lu/page/ article/694/8694/DEU/index.html)

A deeper quantitative as well as qualitative analysis of the results of our inquiry by use of the test sentences in (38) shows that with the quantifiers eng Jett/e hü̈̈u 'a lot of' and genuch/gnüeg 'enough' in (38a-b), our Luxembourgish informants mostly accepted more than one order, that is, two or three different orders for 'a lot of these/such people' (eng Jett där Leit, där Leit eng Jett and/or Där Leit ... eng Jett, etc.). In contrast, our speakers of Walliser German most often ticked only one order (e hü̈̈fu deru/deschi Lit, deru/deschi Lit e hü̈̈u or Deru/deschi Lit ... e hü̈̈fu etc.) and accepted to a much lesser extent two or up to three serializations. With the numeral een/eis 'one', as in 'one of these cookies/tartlets', and with the negative quantifier keen/keis 'none', as in 'any of this beer', illustrated in (38c) and (38d) respectively, on the other hand, in Luxembourgish (een där Kichelcher, där Kichelcher een, Där Kichelcher ... een etc.) as well as in Walliser German (eis deru/deschi Chüechjini, deru/deschi Chüechjini eis, Eis ... deru/deschi Chüechjini etc.), there was a strong preference for selecting merely one of the given serializations. Qualitatively, with (38a) and ( $38 \mathrm{~b}$ ), the first and basic sequence quantifier + partitive phrase (Q PRTV) was the most popular one in both varieties, followed by the third sequence with Split-Topicalization (PRTV ... Q) and, lastly, by the second, (in the Valais only marginal) short raising sequence (PRTV Q). Intraindividual acceptance of the first, second and third or of the first and third positional variant occurred

'We don't have enough of these sausages/of this wine' (http://www.land.lu/page/article/ 694/8694/DEU/index.html) and Ech hätt där Kichelcher gär een 'I'd like one of these cookies' (e.g., Luxemburg-Stadt_1946 in our questionnaires), the partitive DP is extracted, without being topicalized, though, but only raised to the Mittelfeld (middle field). 
frequently. Combinations of the first and second as well as of the second and third variant were very rare. With $(38 \mathrm{c})$ and especially $(38 \mathrm{~d})$ instead, the third serialization pattern (Split-Topicalization: PRTV ... NUM/NEG Q) was (strongly) preferred (except in the case of eis deru/deschi Chüechjini in the Valais), followed by the second pattern (short raising: PRTV NUM/NEG Q) and, finally, the first one (base order: NUM/NEG Q PRTV).

(38) a. Lux.

Ech kennen eng Jett där Leit

a. Wall.

Ich kennu $e$ hü̈̈u deru/deschi Lit

I know a heap the.GEN.PL people

'I know a lot of these/such people.'

b. Lux.

Mir hu net genuch där Wirschterscher kaaf

b'. Wall.

Wier hei nit gnüeg deru/deschi Wurschtjini

we have not enough the.GEN.PL sausages (bought)

'We haven't bought/don't have enough of these sausages.'

c. Lux.

Ech hätt gär een där Kichelcher

I had gladly one the.GEN.PL cookies

c. Wall.

$\begin{array}{lll}\text { Ich wellti } & \text { eis deru/deschi Chüechjini } \\ \text { I } & \text { wanted } & \text { one the.GEN.PL tartlets }\end{array}$

'I'd like one of these cookies/tartlets.'

d. Lux.

Mir brauche keen däers Béier

d'. Wall.

Wier brü̈che keis deschi/deru Bier

we need none the.GEN.sg beer

'We don't need any of this beer.' 
Another point worth exploring in more detail is the co-occurrence of partitive nominals with a partitive pronominal in the case of Split-Topicalization with a stranded indefinite quantifier as in (39) or a numeral as in (40). There seem to be some interesting differences with respect to the optionality or obligatoriness of such a resumptive partitive pronoun (examples from Döhmer $2017,123,125^{-126):}$
An där Beispiller ginn et (der) vill and the.Gen.PL examples gives it (of.them) many 'And there are many of these examples.'
(40) a. D' Airline huet 13 där
b.
13 där
c.
Där
Maschinne
Maschinnen huet
Maschinnen huet
the airline has 13 the.GEN.PL machines has
bestallt
(der) d'Airline (der) bestallt
d'Airline *(der) 13 / (der) 13 Stéck bestallt
the airline (of.them) 13 pieces ordered
'The airline ordered 13 of these planes.'

Our investigation has confirmed that a noun phrase introduced by a partitive determiner (as well as a partitive von-phrase, see also Section 3.2) especially in Luxembourgish can be taken up again by a partitive pronoun, see (41). However, there were two instances of an (optional) resumptive pronoun in Walliser German, too, see (42a) for a case of Split-Topicalization as opposed to (42b), where the entire sequence numeral + dependent partitive phrase is topicalized. Note that, on top of that, the numeral $z \ddot{a} \ddot{a}(n)$ 'ten' bears an additional $i$-suffix (showing also stem alternation) in stranded position in our Highest Alemannic dialects, see (42a) vs. (42b):

(41) a. Där Wirschterscher huet de Michel der zéng giess! the.GEN.PL sausages has the Michel of.them ten eaten

b. Vun dene Wirschterscher huet de Michel der zéng of the.DAT.PL sausages has the Michel of.them ten giess!

eaten

'Michel ate ten of these sausages.' (Luxemburg-Stadt_1946, Ettelbruck 1980, Diekirch_1_1981, Diekirch_1983, Walferdange_1985, Esch-sur-Alzette_1986) 
(42) a. Deru Wurschtjini het $(\mathrm{ra} / \mathrm{ru})$ Beat zä̈̈ni ggässu! the.GEN.PL sausages has (of.them) Beat ten eaten

b. Zää dero Wurschtjini het där Beat (dero) ggässu! ten the.Gen.PL sausages has the Beat (of.them) eaten 'Beat ate ten of these sausages.' (a: Visp_1988, b: Staldenried_1949)

\subsection{Functions/Semantics}

The different functions or interpretations of the noun phrase structures discussed here are somewhat difficult to grasp. In contradistinction to French, the "partitive" determiners in the Continental West Germanic varieties we focused on are only optional, competing with bare nouns, see again the contrasting Luxembourgish examples (taken from Döhmer 2017, 120-121), repeated here as (43a) and (43b):

(43) a. Gitt Beispiller!

give examples

'Give examples!'

b. Mir hunn all Dag där Beispiller

we have every day the.GEN.PL examples

'Every day we have (some) of these examples.'

It is remarkable, though, that in our elicitation we got very often a partitive genitive determiner even with "out of the blue" questions such as Haben wir noch Äpfel? 'Do we still have apples?' (in the given situational context: While preparing a grocery list ...) or Habt ihr auch Bier? 'Do you also have beer?' (During dinner at a friend's home ...). As opposed for example to French and Italian, one would expect a bare noun for an indefinite unspecific reading instead (cf. e.g., Kabatek and Wall 2013). Nevertheless, this was hardly the case in our contrastive test sentence Das sind keine Rosen, das sind Tulpen/Kamelien 'These are not roses, these are tulips/camellias' (At the florist's ...), which triggered almost exclusively a bare noun Tulpen (Lux.) or Kamelie (Wall.). Unlike this contrastive example, Äpfel and Bier in our "out of the blue" contexts are in principle quantifiable and could thus refer to an undetermined quantity. ${ }^{26} \mathrm{And}$ in spite of the given introductory situation, the utterances seem to remain

26 This contrast has also been observed for des-N Ps in French (Ihsane 2008). 
ambiguous between a general question for apples/beer and asking for particular apples/beer ('of these apples/this beer, ... you know').

Although the semantic differences sometimes seem to be quite small, there is often a more or less marked sort of-connotation conveyed by the Germanic "partitive" determiners (i.e., 'such, of this type/that kind'). The partitive noun phrase däers Kéis in the Luxembourgish example (44) apart from 'some of this cheese' can mean 'such cheese'. The same holds for the nominals under (45) däru biähär 'some of these/such books' and deru/deschi Steina/Boone/Epfla 'some of these/such stones/beans/apples' in Walliser German. Hotzenköcherle $(1934,431)$, too, reports on a development from a demonstrative partitive meaning to a sort of-meaning ("talis") for Mutten, a Grisons Walser dialect. For our test sentence $(45 \mathrm{~b})$, however, a slight semantic difference between the two determiners deru and deschi has been reported by some informants, with deru leading rather to a such-interpretation ('of this type') and deschi being more partitive ('some of these stones/beans/apples'). ${ }^{27}$ Sometimes the determiners may also have a '... you know'-reading, as reported for the Dutch vanconstruction (see above Haeseryn et al. 1997).

(44) Luxembourgish

Ech hunn nach däers Kéis doheem

I have still the.GEN.sG cheese at.home

'I still have (some) of this/such cheese at home.' (Döhmer 2017, 2)

(45) a. Valais: Lötschental

däru biähär hetti miär schōn oich
the.GEN.PL books would.have we even also
'We do also have (some) of these/such books.' (Henzen 1932, 122)

b. Valais: Visp Welleder nu deru/deschi Steina/Boone/Epfla?
want.you more the.GEN stones/beans/apples
'Would you like (some) more of these/such stones/beans/apples?'

We can find hints for a kind of-reading also in other German dialects, for

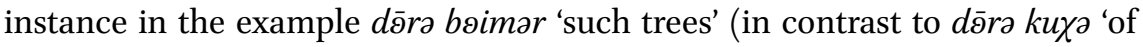
these cakes' and dəsən kuðə 'of this cake', Dellit 1913, 133-134) from Kleinschmal-

27 This is in line with the occurrence of dëre meaning 'such' in other varieties of Swiss German (see fn. 22), not showing any partitivity (anymore). 
kalden (Hennebergisch), an East Franconian dialect. Note, moreover, that in our elicitation tasks aiming explicitly at a sortal reading - by pointing and referring to a specific type of trees/milk/cheese with the aid of an appropriate context description-, a majority of our Luxembourgish informants used the partitive genitive determiner (där (doter) Beem 'such trees (over there)', där (doter)/därer Mëllech 'such milk (over there)', däers/dees (doten) Opschnatt 'such cold meat (over there)'), in competition with sou 'so/such' (sou Beem, sou Mëllech, sou Opschnatt), but in Walliser German, on the other hand, the adjectival formation settigi/-e 'suchlike' (settigi Beim 'such trees', settigi Milch 'such milk', settige Üfschnitt 'such cold meat') was clearly preferred over deru/deschi (deru Beim, deschi Milch, deschi Üfschnitt).

Furthermore, one can wonder if, besides partitive meanings and sort of- 1 kind of-readings, there is also the possibility of a pure indefinite interpretation of independent partitive genitives in (modern) Germanic, comparable to Romance so-called "partitive" determiners, for instance French $d u / d e s$-NPs (cf. e.g., Ihsane 2008) as in J'ai bu du vin 'I drank (some) wine' or Elle a acheté des livres 'She bought (some) books'. Although this question still has to be explored in detail, it strikes us that historical examples of genitive nominals, even with a definite determiner, sometimes clearly allow for an indefinite reading, see (46):

(46) OHG

joh brast in thar thes win-es

also was.lacking them there the.GEN.M wine-GEN.M 'and they also lacked wine.'

Although a generic use of noun phrases with a partitive determiner seems to be very unlikely both in Romance and cross-linguistically, on closer examination this turns out not to be completely excluded. As for Germanic, De Hoop (2003) gives an example for the Dutch "faded partitive construction" van die/dat + (A) $+\mathrm{N}$ (see Section 3.2), reproduced here as (47), which is generic indeed. However, according to her, this is only possible when a modifier is present, that is, in this context the adjective $z$ wart 'black. ${ }^{28}$

28 Thanks to Giuliana Giusti for pointing out to us that dei/delle-phrases with a generic interpretation can be found in Italian as well, both with and without a modifying adjective, for example, Deiveri italiani ... 'Real Italians ..., Delle barzellette devono far ridere 'Jokes have to cause laughter' (Giusti p.c.). They are also possible in French, as discussed in the literature (Vogeleer and Tasmowski 2005; Wilmet 2003; see also Ihsane 2018). 
(47) Van die zwarte katten brengen geluk!

of those black cats bring luck

'Black cats bring good luck.' (De Hoop 2003, 198)

In our paper, we discussed new data gathered in recent questionnaire elicitations and fieldwork in two Germanic varieties known so far very superficially for the survival of genitive forms in nominal phrases potentially rendering notions of partitivity. In our research, we found several types of determiners showing forms going back etymologically to genitive forms or newly formed on such models. There are, however, no more nominal genitives. Although there is no thorough description of the usage of genitive and partitive markers available until now, it is clear that genitive definite determiners mainly function as (optional) partitive markers in our Germanic varieties, denoting a partial reading in deictic contexts as well as sort of-/kind of-readings. These archaic genitive markers seem to decrease in frequency in the younger generation, though, competing particularly with (among other functions) partitive von ('from, of')phrases.

In connection with the findings presented in this paper on some structural and functional aspects of "partitive" determiners in Germanic (with a special focus on Luxembourgish and Walliser German), a number of open questions should be pursued in further research. A first issue concerns the exact relationship between "partitive articles" and pronouns, also contrastively to Romance, since in both language families there are systems with the respective determiner as well as the pronominal (in French, partially also in Italian, in Walliser/Walser German dialects and in Luxembourgish) (cf. Schurr, this volume, for a discussion of some clitic patterns and the bare/partitive distinction in Romance in a usage-based approach). On the other hand, there are also systems possessing only the pronoun, but no "partitive" article (such as Catalan, Dutch and some Central German dialects). This gives rise to a second line of investigation: Why is it that the pronominal use of partitive genitives has survived longer than their use in nominals and thus seems to be more resistant (a fact that ties in with the general observation that case distinctions persist longer in pronouns as opposed to the nominal domain)? And why do we still find genitive case here anyway, in spite of the general loss of the genitive in most dialects? A third issue targets the possible role of the Germanic-Romance contact situation for Walliser and Walser German as well as for Luxembourgish: Has the preservation of partitive forms of the determiner (and/or pronouns) 
beyond fossilized or lexicalized expressions been sustained by Romance contact influence in these varieties? Some researchers considered also the vonconstruction (or at least its increase in the 18th century) to be a product of language contact (Reichmann and Wegera 1993, 353). Finally, the obligatoriness vs. optionality of partitive determiners in different syntactic contexts needs further exploration, similar to the Romance systems (French vs. Italian).

\section{Acknowledgements}

We are very grateful to Sandro Bachmann, Georges Felten and Peter Gilles for their precious help with our Walliser German and Luxembourgish questionnaires as well as to Chris de Wulf for his valuable hints and grammaticality judgments on the Dutch data. Many thanks to all our informants who took part in our indirect elicitations and fieldwork, without them, this work would not have been possible. Furthermore, we would like to thank the editor of this volume and the organizers of the workshop "Bare nouns vs. 'partitive articles': disentangling functions" at the 5oth Annual Meeting of the Societas Linguistica Europaea in Zürich in September 2017 for all their support and great work as well as the participants and audience at the PARTE workshop "Partitive Determiners and Partitive Case" in Venice in November 2017 for the very productive workshop and fruitful discussions. We are also very obliged to the URPP Language and Space for supporting our research within the research focus group Syntax of Nominal Determination in Contact (SyNoDe).

\section{Abbreviations}

$\begin{array}{ll}\text { ENHG } & \text { Early New High German } \\ \text { IE } & \text { Indo-European } \\ \text { LOD } & \text { Lëtzebuerger Online Dictionnaire } \\ \text { Lux. } & \text { Luxembourgish } \\ \text { LWB } & \text { Luxemburger Wörterbuch } \\ \text { MHG } & \text { Middle High German } \\ \text { NHG } & \text { New High German } \\ \text { OHG } & \text { Old High German } \\ \text { OT. } & \text { Old Testament } \\ \text { Wall. } & \text { Walliser German }\end{array}$


O. Otfrid v. Weissenburg, Evangelienbuch, gth c.

Iw. Iwein. Eine Erzählung von Hartmann von Aue, edited by Georg F. Benecke and Karl Lachmann, revised by Ludwig Wolff. 7 th ed. Vol. 1. Berlin 1968: De Gruyter.

Mons. Monseer Fragmente, 9 th c.

Tucher Lexer, Matthias, ed. 1862. Endres Tuchers Baumeisterbuch der Stadt Nürnberg (1464-1475). Stuttgart: Literarischer Verein.

\section{References}

Benecke, George F., and Karl Lachmann, eds. 1968. Iwein. Eine Erzählung von Hartmann von Aue. revised by Ludwig Wolff. 7th ed. Vol. 1. Berlin: Walter De Gruyter.

Bohnenberger, Karl. 1913. Die Mundart der deutschen Walliser im Heimattal und in den Außenorten. Frauenfeld: Huber \& Co.

Brandstetter, Renward. 1904. Der Genitiv der Luzerner Mundart in Gegenwart und Vergangenheit. Zürich: Zürcher und Furrer.

Broekhuis, Hans, and Marcel den Dikken. 2012. Syntax of Dutch: Nouns and noun phrases. Vol. 2. Amsterdam: Amsterdam University Press.

Chambers, Jack K., and Peter Trudgill. 1998. Dialectology. 2nd ed. Cambridge: Cambridge University Press.

Christophory, Jul. 1974. Mir schwätze Lëtzebuergesch. Nous parlons luxembourgeois. Abécédaire luxembourgeois. Guide bilingue de grammaire et de lecture. Luxembourg: Saint-Paul.

Dahl, Östen. 2015. Grammaticalization in the North. Noun phrase morphosyntax in Scandinavian vernaculars. Berlin: Language Science Press.

De Hoop, Helen. 2003. "Partitivity." In The Second Glot International State-of-the-Article Book. The latest in Linguistics, edited by Lisa Cheng and Rint Sybesma, 179-212 (Studies in Generative Grammar 61). Berlin/New York: De Gruyter.

Dellit, Otto. 1913. Die Mundart von Kleinschmalkalden. Laut- und Formenlehre, Syntax und Wortschatz. Marburg: N.G. Elwert.

Döhmer, Caroline. 2017. Aspekte der luxemburgischen Syntax. PhD Diss., University of Luxembourg.

Döhmer, Caroline. 2018. "A New Perspective on the Luxembourgish Genitive." In Germanic Genitives, edited by Tanja Ackermann, Horst J. Simon and Christian Zimmer, 15-36. Amsterdam: John Benjamins.

Fleischer, Jürg, in collaboration with Oliver Schallert. 2011. Historische Syntax des Deutschen. Eine Einführung. Tübingen: Narr.

Gerstner-Hirzel, Emily. 1979. Aus der Volksüberlieferung von Bosco Gurin. Sagen, Berichte und Meinungen. Märchen und Schwänke. Basel: Krebs (Schriften der Schweizerischen Gesellschaft für Volkskunde 63). 
Gilles, Peter. 2006. "Dialektausgleich im Luxemburgischen." In Perspektiven einer linguistischen Luxemburgistik. Studien zu Diachronie und Synchronie, edited by Claudine Moulin and Damaris Nübling, 1-28. Heidelberg: Winter.

Giusti, Giuliana. This volume. "A Protocol for Indefinite Determiners in Italian and Italo-Romance."

Glaser, Elvira. 1992. "Umbau partitiver Strukturen in der Geschichte des Deutschen." Sprachwissenschaft 17, no. 2: 113-132.

Glaser, Elvira. 1993. "Syntaktische Strategien zum Ausdruck von Indefinitheit und Partitivität im Deutschen (Standardsprache und Dialekt)." In Dialektsyntax, edited by Werner Abraham and Josef Bayer, 99-116. Opladen: Westdeutscher Verlag.

Glaser, Elvira. 1995. “Die syntaktische Nullstelle-eine Kennform des Alemannischen?” In Alemannische Dialektforschung. Bilanz und Perspektiven. Beiträge zur 11. Arbeitstagung alemannischer Dialektologen, edited by Heinrich Löffler, 65-79. Tübingen/ Basel: Francke.

Glaser, Elvira. 2008. "Syntaktische Raumbilder." In Dialektgeographie der Zukunft, edited by Peter Ernst and Franz Patocka, 85-111. Stuttgart: Franz Steiner.

Glaser, Elvira, and Gabriela Bart. 2015. "Dialektsyntax des Schweizerdeutschen." In Regionale Variation des Deutschen. Projekte und Perspektiven, edited Kehrein, Roland, Alfred Lameli and Stefan Rabanus, 81-107. Berlin/Boston: De Gruyter.

Grestenberger, Laura. 2015. "Number marking in German measure phrases and the structure of pseudo-partitives." Journal of Comparative Germanic Linguistics 18, no. 2: 93-138. https://doi.org/10.1007/s10828-015-9074-1.

Grieshaber, Franz Karl, ed. 1844/1846. Deutsche Predigten des XIII. Jahrhunderts. Erste Abtheilung/Zweite Abtheilung. Stuttgart.

Haeseryn, Walter et al. 1997. Algemene Nederlandse Spraakkunst. 2 volumes. 2nd ed. Groningen/Deurne: Martinus Nijhoff uitgevers/Wolters Plantyn. Ebook, http://ans .ruhosting.nl/e-ans.

Hentschel, Elke. 1993. "Flexionsverfall im Deutschen? Die Kasusmarkierung bei partitiven Genetiv-Attributen." Zeitschrift für germanistische Linguistik 21: 320333 .

Henzen, Walter. 1932. "Der Genitiv im heutigen Wallis." Beiträge zur Geschichte der deutschen Sprache und Literatur 56: 91-138. https://doi.org/10.1515/bgsl.1932.1932.56.91.

Hotzenköcherle, Rudolf. 1934. Die Mundart von Mutten: Laut- und Flexionslehre. Frauenfeld: Huber.

Ihsane, Tabea. 2008. The layered DP in French. Form and Meaning of French Indefinites. Amsterdam/Philadelphia: John Benjamins.

Ihsane, Tabea. 2018. "Preverbal subjects with a partitive article: the case of Francoprovençal in the Aosta Valley." Talk given at SLE 51, Workshop Preverbal Indefinite Subjects, Tallinn University (Estonia).

Kabatek, Johannes, and Albert Wall. 2013. New Perspectives on Bare Noun Phrases in Romance and Beyond. Amsterdam/Philadelphia: John Benjamins. 
Kolmer, Agnes. 1999. Zur MAss/counT-Distinktion im Bairischen: Artikel und Quantifizierung. Arbeitspapier 34. Köln: Institut für Linguistik, Universität zu Köln.

Koptjevskaja-Tamm, Maria. 2001. “'A piece of the cake' and 'a cup of tea': Partitive and pseudo-partitive nominal constructions in the Circum-Baltic languages." In CircumBaltic Languages. Typology and Contact. Vol. 2: Grammar and Typology, edited by Östen Dahl and Maria Koptjevskaja-Tamm, 523-568. Amsterdam/Philadelphia: John Benjamins.

Koptjevskaja-Tamm, Maria. 2006. "Partitives." In Encyclopedia of Language \& Linguistics. 2nd ed. Vol. 9. 218-221. Amsterdam: Elsevier.

Lenz, Alexandra N., Jürg Fleischer, and Helmut Weiß. 2015. "Syntax hessischer Dialekte (SyHD)." In Regionale Variation des Deutschen. Projekte und Perspektiven, edited by Kehrein, Roland, Alfred Lameli and Stefan Rabanus, 261-287. Berlin/Boston: De Gruyter.

Letsch, Walter. 2018. Ein schön Kochbuch 1559. Das älteste deutschsprachige Kochbuch der Schweiz. Chur: Desertina.

Lexer, Matthias, ed. 1862. Endres Tuchers Baumeisterbuch der Stadt Nürnberg (14641475). Stuttgart.

Luraghi, Silvia, and Tuomas Huumo, eds. 2014. Partitive cases and related categories. Berlin/Boston: De Gruyter.

Luraghi, Silvia, and Seppo Kittilä. 2014. "Typology and diachrony of partitive case markers." In Partitive cases and related categories, edited by Silvia Luraghi and Tuomas Huumo, 17-62. Berlin/Boston: De Gruyter.

Lux-Bintner, Sonja. 2014. 'Schwaarze Schockela.' Néng batter-séiss Geschichte fir Leit mat Humor. Luxembourg: Saint-Paul.

Martin, Fabienne, Janayna Carvalho and Artemis Alexiadou. This volume. "Predicates of Personal Taste and Pancake Sentences in Brazilian Portuguese and French."

Müller, Christina Cornelia. 2010. Transkription des Kochbuches der Wiborada Ziliaus St. Gallen. Master's thesis. University of Zürich.

Nishiwaki, Maiko. 2010. Zur Semantik des deutschen Genitivs. Ein Modell der Funktionsableitung anhand des Althochdeutschen. Hamburg: Buske.

Oosterhof, Albert. 2005. Verbleekte partitieven: descriptieve, syntactische en semantische aspecten. Neerlandistiek.nl 05.04: 1-28.

Reichmann, Oskar, and Klaus-Peter Wegera, eds. 1993. Frühneuhochdeutsche Grammatik. Tübingen: Niemeyer.

Schanen, François, and Jacqui Zimmer. 2006. 1, 2, 3 Lëtzebuergesch Grammaire II-Le groupe nominal. Esch-sur-Alzette: Editions Schortgen.

Schurr, Hagay. This volume. "Bound to be? Bare and Partitive-Marked Noun Phrases in Romance Languages and the Emergence of Prominence-Conditioned Patterns."

Scott, Alan K. 2014. The Genitive Case in Dutch and German. A Study of Morphosyntactic Change in Codified Languages. Leiden/Boston: Brill. 
Selkirk, Elisabeth O. 1977. "Some remarks on noun phrase structure". In Studies in formal syntax, edited by Adrian Akmajian, Peter W. Culicover and Thomas Wasow, 285-325. London/New York: Academic Press.

Seržant, Ilja A. 2014. "The Independent Partitive Genitive in North Russian." In Contemporary Approaches to Dialectology. The Area of North, Northwest Russian and Belarusian Dialects, edited by Ilja A. Seržant and Björn Wiemer, 270-329. Bergen: Department of Foreign Languages.

Stark, Elisabeth, and David Paul Gerards. This volume. "Partitive Articles" in Aosta Valley Francoprovençal-Old Questions and New Data."

Stopp, Hugo, ed. 1980. Das Kochbuch der Sabina Welserin. Mit einer Übersetzung von Ulrike Giessmann. Heidelberg: Winter.

Stopp, Hugo, in collaboration with Renate Ertl and Angelika Schmitt. 1980. Aus Kochbüchern des 14. bis 19. Jahrhunderts. Quellen zur Geschichte einer Textsorte. Heidelberg: Winter.

Strobel, Thomas. 2017. Pronominale Partitivität: Arealität und Mikrovariation einer morphosyntaktischen Variable in den Varietäten des Deutschen. PhD Diss., Goethe University Frankfurt. http://publikationen.ub.uni-frankfurt.de/frontdoor/index/index/ $\operatorname{docId} / 44424$.

Szadrowsky, Manfred. 1937. "Zur hochalemannischen Syntax v." Beiträge zur Geschichte der deutschen Sprache und Literatur 61: 273-288.

Szadrowsky, Manfred. 1940. "Ein wehrhafter Fall." Bündnerisches Monatsblatt August 1940, Chur: 225-238.

Vogeleer, Svetlana, and Liliane Tasmowski. 2005. "Les $N$, un $N$ et des $N$ en lecture générique." In Déterminants indéfinis en français, edited by Svetlana Vogeleer and Liliane Tasmowski, 53-78. Brussels: Duculot.

Weber, Albert. 1987. Zürichdeutsche Grammatik. Ein Wegweiser zur guten Mundart. 3rd ed. Zürich: Hans Rohr.

Weise, Oskar. 1906. "Der Teilungsgenetiv in den Mundarten." Zeitschrift für deutsche Mundarten 1: 289-295.

Weiß, Helmut, and Thomas Strobel. 2018. "Neuere Entwicklungen in der Dialektsyntax.” In Linguistische Berichte 253:3-35.

Wilmet, Marc. 2003. Grammaire critique du français. Brussels: Duculot.

Wipf, Elisa. 1910. Die Mundart von Visperterminen im Wallis. Frauenfeld: Huber.

Zimmer, Christian. 2015. “'Bei einem Glas guten Wein(es)': Der Abbau des partitiven Genitivs und seine Reflexe im Gegenwartsdeutschen." Beiträge zur Geschichte der deutschen Sprache und Literatur 137:1-41.

\section{Unpublished Ms.}

ms. around 1550 Arzneibuch der Philippine Welser (Wien, Kunsthistorisches Museum Inv.Nr. PA 1474). 